\title{
Employment and Gross Value Added Generated by Port Infrastructures: A Bibliographical Review and Empirical Findings to Support Policy Maker Decisions
}

\author{
Ignacio de la Peña Zarzuelo
}

A relevant factor to be considered by policy makers is the economic impact of their decisions on port investments. A structured system for assessing the economic impact of port infrastructures was developed in the mid-60s in the USA. From then, a great number of works in this field has been carried out considering different geographical environments and using different methodologies and approaches. In this work, a complete set of 27 Spanish ports are reviewed, first from a chronological point of view and later establishing a comparative analysis of different indicators of port productivity. Special focus is put on comparing the contribution of the ports in generating employment and creating Gross Value Added generated in the local and regional economy. Direct, indirect, and induced impacts in both the port industry and the industry dependent on the existence of the port and its activities are considered.

\section{KEY WORDS}

$\sim$ Economic impact assessment

$\sim$ Port economics

$\sim$ Port performance

Universidad Politécnica de Madrid, Spain

e-mail: ipena@unionfenosagas.com

doi: 10.7225/toms.v10.n01.012

This work is licensed under (cc) BY

Received on: Aug 30, 2020 /Revised on: Oct 20, 2020 / Accepted on: Nov 7, 2020 / Published online: Mar 31, 2021

\section{INTRODUCTION}

\subsection{Background}

The development of Economic Impact Assessments in Ports (hereafter, EIAP) dated back to the 1960s in the USA (Anderson, 1964; Schenker, 1965; Schenker, 1967; Hille and Suelflow, 1969). These pioneer studies were followed by a series of works covering the same geographical region and sharing both common ground and methodology, trying to evaluate either the global impact or the unitary impact of port activities in terms of the labor market and the income levels of the region.

Waters (1977) criticized the use of these studies as well as pointed out some conceptual errors of his precursors and suggested certain improvements in the models carried out until then. Academically, his most relevant influence is to import the input-output methodology (hereafter, IOM) to the EIAP.

Chang (1978) replied to the criticism of the latter author by defending the EIAP as a useful tool for port managers, while Little (1979) presented the most relevant work ever in this field. This is the "Port Economic Impact Kit" (hereafter, PEIK) developed for the U.S. Maritime Administration (MARAD). This work provides a methodological standardization that has been followed by hundreds of subsequent reports.

PEIK has been a key element for comparing different studies and their respective outcomes. In synthesis, this methodology is an ad hoc development for the port industry of the Leontief's 
input-output models (Leontief, 1966). From its launch, this methodology has been successively updated and improved (MARAD, 1982; Temple et al., 1985; MARAD, 1995).

\subsection{Contribution to Research}

Since some administrations or institutions have developed standard rules for implementation and a relevant number of works have been published over the years, it is possible to develop a comparative analysis of different ports or types of goods, as well as to analyze the evolution of the impact of a particular port in which different studies have been developed in different years. Moreover, since many studies are available, it is possible to develop a simple approximate formula to estimate the productivity, job generation, and expected economic impact of a port by using only its traffic throughput as input. In this paper, 6 formulas are provided to assess in a simple way: i) Gross Value Added (hereafter, GVA), ii) Employment and, iii) Port Productivity both in the port industry and in the economy dependent on the port industry

\subsection{Outcome and Limitations of the Paper}

This paper attempts to resolve the lack of benchmarking between different EIAPs. It analyzes the relationship, if any, between the size of the port and its GVA, the number of jobs it generates and its productivity (measured as GVA/job). It also discusses the possible influence of traffic structure ( \% general cargo) on the economic impact of the port.

The analysis covers only one set of 41 studies within the Spanish Port System. Therefore, the conclusions can only be applied to those environments with similar characteristics.

\subsection{Structure of the Paper}

Apart from the Introduction, the paper is divided into five additional sections. Section 2 describes the material and methodology and provides an intensive literature review. Section 3 presents the methodology used in the study and the data collected for further calculations, which are discussed in the same section. Section 4 includes the calculation of the new formulas that explain the contribution of this research. Section 5 summarizes the conclusions of the research. Finally, Section 6 points out future research areas.

\section{MATERIAL AND METHODS: BIBLIOGRAPHICAL REVIEW AND EVOLUTION}

Apart from the US case, it is difficult to find another port system where as many EIAPs have been carried out as in Spain. This is not only true for the total number of studies developed, but also for the number of ports assessed, the methodologies used or the differences in geographical scope (local, regional, supra-regional or national).

The main gap observed in the literature review conducted in this study has to do with the absence or lack of self-criticism and inclusion of in-depth analyses on the different methodologies used in each of these reports. In other words, most of the papers have a commercial approach that tries to put a value on the positive impacts of the ports rather than provide a scientific view of both the methodology used and its results. In general, few papers show how studies have evolved over time and how subsequent reports have addressed the methodological limitations of their precursors.

EIAPs in Spanish Port System (hereafter, SPS) existed for more than 25 years before Fraga and Seijas (1992) addressed the impact of the port of Ferrol and de Rus et al. (1994) focused on the ports of la Luz and las Palmas. These first contributions were limited to analyzing the direct impacts of these port infrastructures, without using the IOM methodology.

At the same time, Martínez (1993) submitted his doctoral thesis entitled "The economic impact of the ports. The case of the Spanish Port System" and a few years later, the same author published a new report that treats the SPS under an econometric approach (Martínez, 1996). In the latter paper, the author presents different cost functions while classifying ports considering their respective characteristics. He concluded that the SPS could be considered as a natural monopoly.

Fraga and Seijas (1992) used a direct estimation method based on two different data sources. First, data provided by companies and institutions operating in the port (collected through an intensive survey campaign) and then cross-checked with data from official registers.

The results are compiled in terms of employment generated and business income, and represent a static view (applicable to the year 1990) and are relatively limited in terms of the area covered by the study, i.e. a small sub-regional area comprising 22 municipalities in the vicinity of the port (Ferrolterra).

The authors consider the businesses that operate in the port in two separate groups: the "dependent industry" (the internal activity of the port) and the "final customers of the port" (businesses that use the port, but the port is not the core of their respective businesses). If the port did not exist, the first group of dependent firms would not exist either, as their activities are inextricably linked to the existence of the port (typically port service providers).

Rus et al. (1994) calculated the income, employment, Gross Value Added, and fixed assets of the port industry, also using a direct estimation approach to provide an overview of the economic weight of the various actors using the ports. In this study, the authors also discussed the impact of the different cost elements within the port. Again, this is a static view (the 
year 1992) and limited in scope (direct effects of port activities without considering indirect or induced effects).

Funded by the Ente Público Puertos del Estado (EPPE), Spanish Port Agency dependent on the Ministry of Public Works, the consulting firm TEMA developed an adaptation of the PEIK in the version of Temple et al. (1985) applicable to SPS. This methodology is applied in a pioneering way to a system consisting of five Port Authorities of the Galicia Region (Ferrol, A Coruña, Vigo, Vilagarcía and Marin-Pontevedra), first assessing the impact of these ports on the regional economy (TEMA, 1994a) and later the impact of the same ports on the whole national economy (TEMA, 1995).

Villaverde and Coto (1995) used the IOM to analyze the impact of the port of Santander, and Coto and Martínez (1995) used the same methodology to evaluate the impact of the entire SPS. These authors used data published in 1992 (referring to the year 1989) and concluded that the SPS contributed more than $3.0 \%$ of the Gross Value Added at market prices (GVAmp) and more than $3.3 \%$ in terms of generated employment in Spain.

These last reports are the first in the SPS, in which not only the direct effects are evaluated, but also the indirect and induced effects are considered.

The Port of Santander, together with the Port of Ferrol, is probably the most studied environment in this context within the SPS. Following the work of Villaverde and Coto (1995) cited above, we find a large number of reports, highlighting the work of Villaverde and Coto (1996, 1997, 1998), Mateo (2010), Mateo et al. (2012), and Parra et al. (2013).

While most of the above-mentioned studies focused exclusively on the impact of this port on the Santander region, the last two papers go further by considering the impact of the port in a supra-regional context, covering the entire hinterland of the port (adding the regions close to Santander that use this port in their respective logistics chain and transport network).

Bilbao Plaza Marítima (1995) studied the port of Bilbao, while TYPSA (1995) focused its efforts on the port of Motril. While the first work used the IOM (based on 1990 data to calculate the impact on the Basque Country Region until 1993), the second work introduced simulation techniques and economic indices extrapolated from other previous studies.

After these works, EPPE (1996) carried out a study related to the port of Algeciras and Bilbao Plaza Marítima (1998); another work focused on the port of Marin. In the latter study, a double geographical scope is adopted: first, the impact of the port in 1996 is analyzed over the province of Pontevedra and then the impact of the port on the region of Galicia.

Both studies used the 1990s regional input-output matrix (IOMat), published in 1995, which points to one of the most criticized points of this methodology, namely the underlying assumption that the regional economic structure remains unchanged from the time of publication of the data, and therefore that the economic linkages between sectors remain unchanged over such a long period.

CONSULTRANS and CEET (1998) published their report on the ports of Tarragona and Barcelona. These studies used two different approaches to compare different methodologies. On the one hand, they used the classical IOM approach (with 1987 data, published in 1995). On the other hand, they conducted an in Natura econometric model. Further references to these studies can be found in Pérez and García (2004).

Lebón (1998) presented a study on assessment of the impact of the Port of Seville, which is the first study in a very complete series focusing on this Port Authority (hereafter, PA), which will be discussed later.

García del Hoyo et al. (1999) studied the port of Huelva and Martínez et al. (1999) focused on the port of Santa Cruz de Tenerife. Both used the same methodology to assess the impact of these ports on the economy of the province in which they are located.

Castillo et al. (2004) provide an interesting comparison of the works published between 1992 and 2000. This paper also discusses the use of this methodology to evaluate the appropriateness of new port investments. The authors introduced some recommendations to standardize the results and facilitate comparison exercises.

This first summary study is later updated by RodríguezDapena (2005), who considers the period 1992-2005. This author pointed out that a large number of reports were published in the early 2000s, i.e. Castellón, Bilbao, Valencia, Ceuta, Seville, and Almería.

As far as the port of Seville is concerned, the calculations refer to 1995 (using 1990 data), using a novel approach that the authors call "localization coefficient", which allows them to import regional data to a provincial level. In relation to the report on the port of Almeria, the authors apply the methodology both at the regional level (Andalusia) and in the local context (province of Almeria), using the last available data (1995). The work related to the port of Castellon uses data from Valencia region (1990 data, updated to 1997). The study on the port of Ceuta is somewhat different from the previous ones, as Ceuta is an autonomous city in Spain (located in the north of Africa and not included in any Regional Government) and the study focuses only on the economic impact in the city of Ceuta.

A first study with a dynamic approach is presented in Loveras (2005). It compares the results of the economic impact of the Port of Barcelona in different years. First, the impacts related to the year 1995 (as compiled in CONSULTRANS and CEET 1998), and then an update of the impacts to the year 2000 developed for this author. Apart from the effort to produce new IOMats, this work is also noteworthy because it introduces the assessment of the impacts of different business sectors of the PA (the port impacts are divided into individual impacts of dry bulk, 
liquid bulk, general cargo, and containers) and different sectors (passenger, fishing, and automotive industry).

Bilbao PA also developed a second study using this dynamically oriented approach by comparing data from 1995 (Bilbao Plaza Maritima 1995) and 2000 (KPMG, 2000). Another novel approach in this last report considers a purely dynamic methodology by evaluating the impact of the PA investment plan for the period 1991-2004. In essence, the model abandons the classical approach of the total income of each actor to take into account all activities affecting a given product. A few years later, the same port is analyzed again (Deloitte, 2016), assessing the impact of different activities (freight, cruise and passenger traffic, port investment and port-related industrial activities) and six different aspects of contribution (economic, organizational, environmental, social, relationship and reputation).

Rey et al. (2002) assessed the impact of the port of Cadiz while Bernal and García $(2003,2005)$ assessed the port of Cartagena, first locally (Bernal and García 2003) and then regionally (Bernal and García, 2005). In the 2000 publication (referring to 1995), the latter authors used the IOMat the regional level (capturing the intersectoral input-output relationship in the Murcia region), but applied the same methodology to the national matrices (intersectoral input-output at the Spanish level), in order to point out a second classic criticism of these techniques and to estimate the discrepancies (the applicability of the tables obtained in different economic sectors, assuming that the relationship remains unchanged or at least accurate enough).

Castillo et al. (2003a, 2003b) returned to analyze the port of Seville, updating previous reports published by the same authors in López and Castillo (2001). This work was continued in Castillo (2005) and Castillo et al. (2007). They represent an interesting exercise in which the economic impact of a port can be analyzed in an evolutionary way. In the first work, the authors used the IOM with the 1990 data (calculating the impact in 1995), while in the following works they used the data updated to the year 2000. In these evaluations, the authors used the localization coefficient, which allows them to use the provincial-level matrices mentioned above.

Castillo et al. (2003a) emphasize that previous EIAP studies introduce a double-counting effect in terms of the relationship between the port industry and the port-dependent economy. They propose to subtract from the total effect (direct, indirect and induced effects) both the indirect effect of the port industry and the induced effect related to the consumption of indirect employment in the port industry (since these are included in the direct effect of the dependent economy in the first and in the induced effect of the dependent economy in the second case).

Castillo et al. (2003b) offered an alternative methodology to solve the limitations associated with the static nature of classical input-output Leontief-approach. They combined this methodology with econometric estimates based on dynamic simulation. Their model simulated the berthing process in the port of Seville, taking into account the impact of infrastructure improvements and cost reduction measures as well as how this affects the competitiveness of the port compared to other nearby ports (Huelva and Cadiz). Once the decision-making process is simulated, it will be linked to the investment and employment parameters through the data from the economic impact assessment of the port, developed according to the standard EIAP methodology. The results are forecast in a 10-year horizon by running two linear regression models: the first linking GDP and port traffic, and the second linking employment and port traffic.

New studies on the ports of Gijón and Aviles were developed by Villaverde et al. (2003), following the methodology presented in TEMA (1994a). They studied the impact of both ports on the economy of Asturias in 1995 and 2000, continuing the previous work on the same ports included in Aza et al. (2000), and Canal et al. (2001), referring to the year 1995. Villaverde et al. (2003) use the 1998 data in terms of the 1995 input-output intersectoral relationship, assuming that this economic structure has not changed since 1995 and that the year 2000 is only fuzzily applicable. This work provides an interesting comparative exercise between two different years, explaining how and why the impact of ports has evolved over this period. Aza et al. (2004) returned to analyze the port of Gijón and evaluate the impact of a major expansion project, while Fernández (2010) returned to evaluate the port of Avilés.

Pérez and García (2004) selected and reviewed 16 Spanish Ports EIAPs. After criticizing their main limitations and methodological shortcomings, they proposed a new theoretical model based on a multiregional and multisectoral IOM. These authors emphasized that apart from the well-known limitations of the input-output methodology (i.e. static nature, assumption that the economic model remains unchanged despite the gap between data collection and publication, and the certainly simplistic approach), the EIAPs have two major shortcomings: first, the lack of accuracy in assessing how the port's impacts are distributed in the port's actual hinterland, and second, the lack of a specific column in the matrix reflecting the costs of the firms operating in the port and a specific row in the same matrix summarizing the port users and the main customers of the firms operating in the port. Although this work only provides the theoretical description of the new model, it is announced that a new IOM has been prepared in relation to the year 1995 and updated to the year 2002 to be applied to the ports of Vigo and Pasajes from a practical point of view, and that a new "Methodological Guide for the Economic Evaluation of Ports" has been elaborated for EPPE.

Rodríguez-Dapena (2005) presents a complete work, first providing a new, additional methodological overview, while at the same time offering a very interesting comparative exercise 
in relation to 21 Spanish Ports. This author separately considers the impact of port industries and port-dependent industries, and discusses methodological issues about the use of forecasting tools in the context of EIAPs. The researcher notes that EIAPs can be used either as a static analysis of an existing port or as a tool to evaluate future expansion plans by performing forecasting and simulation techniques (on an ex-ante or ex-post basis) and comparing different scenarios (including complete cessation of port activities, changes in port demand, critical changes in port tariffs or the administrative and regulatory framework, etc.).

Berando de Quirós (2005) published a new paper summarizing the experience of SPS in developing EIAPs and presents the "Guidelines for the assessment of the impact of port activities and their practical application in a set of ports" developed by TYPSA for the EPPE in 2004, applied to the ports of Pasajes, Marín, Vigo and Vilagarcía. These guidelines are an update of the pioneer model carried out by TEMA (1994a). Later, Perea and Gaona (2007) provided the practical results of this work by comparing two productivity indices of these ports. The selected indices for comparison were GVAmp per ton of traffic handled at the port and per-unit employment generated by the port. In addition, the results of this new model were compared with the results that would have been obtained with the previous model. However, the main contribution of this work is the impact evaluation software package and the IOM included in it, developed for each of the seventeen regions of Spain plus two additional ones covering the autonomous cities of Ceuta and Melilla (Spanish cities in North Africa). These matrices include 27 sectors, and each of them is formed of 513 columns and 513 rows. With this package, it is possible to construct the EIAP over each specific Spanish Port and obtain different multipliers (as production, demand or supply multipliers).

Lago (2005) considered again the port of Gijón by offering a comparison of several studies in this infrastructure developed with 1995 data (Aza et al., 2000, Canal et al., 2001) and 2000 data (Aza and Baños, 2003; Villaverde et al. 2003; Aza, Baños, Lago and Canal, 2004) using the two approaches described in RodríguezDapena (2005): the first analyzing statically the effects of the port in the region and the second analyzing the effect of its expansion plan.

Castillo (2005) compared the results of the ElAPs developed in Algeciras, Seville, and Ceuta with regard to four different geographical scopes (in growing scale: local, sub-provincial, provincial and regional levels), while Bernal and García (2005) used a similar approach covering the ports of Cartagena and Lloveras (2005), assessing the port of Barcelona.

De Rus et al. $(2007,2009)$ returned to the pioneer studies of Rus et al. (1994) about Las Palmas port. In their study, the authors use the 2002 data updated to 2005 . Their main contribution is the effort made in terms of classifying the direct impact of the port industry (divided into 12 groups), representing a complete review of port service providers, different port terminals, PA activity, etc.

The port of Motril is in the focus of Fernández (2007). This author updates the first paper on this port made by TYPSA (1995), a firm that also assessed the impact of the port of Malaga (TYPSA, 2007).

CONSULTRANS performed two studies with the same methodological approach, covering Castellón (CONSULTRANS, 2008a) and Ferrol (CONSULTRANS, 2008b).

Acosta et al. (2009a) published a new study about the port of Tarifa, in which the existing situation (as of 2007) is compared to a future scenario developing an expansion plan (forecasting the traffic until 2015 and evaluating the impact in the same year). The study not only assesses the impact on the municipality of Tarifa, but also the impact of this port on the province and region where it is located (Cádiz and Andalusia respectively). The authors used the regional 2000 IOMat (published in 2006). The matrix accounts for 86 sectors, while the authors simplify it to only 30 to reduce the complexity and improve the comprehensibility of the results.

APB and CAEB (2010) and Rúa et al. (2014) covered the set of ports depending on the Baleares PA (the Balearic Islands). The first two assessed the impact of these ports in 2007 and the second in 2011. As a new contribution, Rúa et al. (2014) used a phased approach in which first the direct impact of the port industry is estimated, and then the indirect and induced effects are calculated using the IOM. For evaluating the direct impact of the port industry, the authors used data provided by the financial statements and loss and profits accounts of these companies, available data from public registers, and both sectorial and ad hoc reports on these companies' activities). This work represents a good example of how data can be disaggregated for public information purposes as the report not only provided the classical results in terms of the overall direct, indirect or induced effect, but also in terms of each particular port (Palma de Mallorca, Alcudia, Mahón and Ibiza-La Savina) and each particular sector. Port activities are divided into 8 main sectors and 4 specific business areas, i.e. PA contribution, investments, cruises, and marina and leisure nautical sectors).

Following the path of López and Castro (2001), Coronado, et al. (2012), and Coronado et al. (2016) focused on the port of Algeciras to assess the impact of this port in the years 2007 and 2014 (data from 2005 and 2010). A proper comparison between these two works cannot be made for two main reasons: firstly, because in the second study the effects of the investments of the PA and the fishing industry are added while in the first one they are not considered, and secondly, because the structure of the dependent industry is not identical and in the second report it is reformulated. This reformulation is made to align this study with a macro-project developed by PriceWaterHouse Coopers for the public Agency of Ports of Andalusia covering the set of all ports of this Region (PWC, 2017). 
CEET (2009) targeted the Port of Alicante using the same methodology introduced in CONSOLTRANS and CEET (1998) for the ports of Barcelona and Tarragona described above.

Martí et al. (2009) worked for Valencia PA in a report covering the overall and individual impacts of the three ports dependent on such administration (Gandía, Sagunto, and Valencia).

Coronado et al. (2009b) focused specifically on the effects of the traffic of containers in the Port of Algeciras.

Mateo and Coto (2010) studied the impact on the regional economy of the different traffic segments of the Santander PA (i.e. dry bulk, liquid bulk, and general cargo). This study was carried out with the 2005 data and as per own authors' statement. This is the first study that introduces a novel approach to traffic sector segmentation in the SPS. Mateo et al. (2010) focused on the same port to present an assessment with a different geographical scope: first in terms of the region of Cantabria and second covering a broader hinterland of this port (including the regions of Castilla and León, Madrid, Catalonia, and the Basque Country). The results of this last study are compared with those developed with the data of 1993 (Villaverde and Coto 1995) and 1998 (Coto et al. 2001).

De Rus et al. (2010a) worked on a macro project financed by the Ministry of Public Works to evaluate the economic impact of transport projects, which the authors applied to Sagunto Port as an experimental base. In this project, the classic IOM approach is abandoned and a cost-benefit approach is adopted to calculate the impact of port activities in two different scenarios (with and without developing a port expansion) and considering new traffic captured by the new investment.

Guarnido et al. (2010) submitted a new EIAP study covering the port of Almeria and its impact in the province of Almeria and in the region of Andalusia, which represents a continuation of the work made in this port by Jaén et al. (2001).

Coto et al. (2010a, 2010b) published a generalist work about the EIAPs carried out on the SPS, which is followed by Castillo and López (2012), who presented a critical thought about the usage of this EIAPs as a public relation tool in an environment of overall overinvestment in the SPS.

Acosta et al. (2016) applied to the port of Cadiz the identical methodology to Coronado et al. $(2012,2016)$ in previous studies about Algeciras port. This is an interesting contribution in terms of data segregation following other studies described above. In this study, data is presented in terms of direct, indirect, and induced effects and split into different sectors and industries (fishing and cruises included) and cargo categories (dry bulk, liquid bulk, bull break general cargo, container, Ro-Ro, fishing, cruises and passengers, port supplies and "others"). The level of segregation results in very useful information for port managers and decision-makers. This port was covered by previous studies related to the year 1998 (Rey et al. 2002) using the 1995 IOMat and the year 2006 (Coronado et al. 2009) using the 2005 IOMat.

Cartagena port is covered by Ramos et al. (2014) and Artal et al. (2016) as a continuation of the works of Bernal and García (2003, 2005), also using an IOM approach and data from 2011. However, any comparison between these two sets of reports has to be made carefully since the former uses regional matrices, but the latter evaluates the effects on the regional economy by using the national matrices (assuming implicitly that the structure of the economic relationship between sectors remains the same at the regional and national level). This study offers the results in terms of different traffic segments (cruise sector included) and an interesting comparison of the impact of the port in the regional economy compared with other ports of the SPS (Cádiz, Santander, Almería, and Cartagena).

Recently, some Spanish Port Authorities and the municipalities in which the ports are located have been paying close attention to the cruise sector because of the benefits that it brings in terms of high-quality tourist attraction, consumption by the cruise passengers in the city at which the cruise calls, and the related tax generation effect by this sector. University of Barcelona (2014) developed a specific study dealing with this sector and its effects in the area of influence of the Port of Barcelona. To estimate the direct impact a broad campaign of interviews and surveys were carried out (including cruise passengers and other tourists visiting Barcelona as well as those companies providing services to this sector) and they were completed with a bibliographical review on the matter. An IOM was also adopted and the results were presented in terms of incomes, employment, tax generation, and impact on the GDP at two different levels, Barcelona city and Catalonia region. The specific case of the impact of the cruise industry in the Port of Barcelona is also presented in Vayá et al. (2016).

Sanchez and Moreno (2016) addressed the port of Huelva, applying the same methodology described above for Cadiz and Algeciras. The direct, indirect, and induced effects of the port industry and port-dependent industry are analyzed in parallel (using the year 2000 IOMat of Andalusia) while taking into consideration both scenarios with and without the effect of the investments to be carried out by the PA. However, this study is more limited in scope since it does not consider sectors such as cruise, fishing industry, and leisure nautical and recreational sector, which are not as represented in the port of Huelva as they are in other ports, and it does not compare the results with other previous reports (García del Hoyo et al. 1999). This is probably due to the substantial methodological differences between the two studies.

UPV (2017) considered Valencia PA (hereafter, APV) with data from 2015. In this report, the impact is segregated in the 
three ports of the APV (i.e. Valencia, Sagunto, and Gandía). Although the results are divided in the same way as most of the EIAPs (distinguishing between direct, indirect, and induced effects), they are presented in a different format. The work defined the so-called "initial impact", which corresponds to the impact of the port industry in the region, and the "impact on the Region of Valencia" in which the effects of the port-dependent industry and the indirect and induced effects are captured. Based on this study and with a clear informational intention, a detailed explanatory brochure of the study is edited by APV to illustrate the political, social, and economic agents about the economic importance of the port. On top of the classical effects addressed in other studies, other impacts are also evaluated such as the impact of port activities in salaries and wages, company profits, and tax collection at the regional level. As another added value outcome of the study, a comparison of the competitive position of the APV regarding other similar ports is also included (in terms of employment and GVA generation per unit of traffic). This last subsection of the study relies on an international benchmarking provided by Merk and Notteboom (2013), and OECD (2014).

Finally, in the year 2018, a new report was presented covering the seven Port Authorities of the Andalusia Region (PWC, 2017). This super-project was financed by the Public Agency Ports of Andalusia to standardize the methodology used in these ports and follow up periodically the evolution of these ports and their economic impact in the region. The study covered 7 Andalusian PAs, but only the aggregated values were published, showing the effect in terms of employment $(86,061$ jobs) and GDP ( $€ 5,695$ million, i.e. $3.1 \%$ of the GDP of the region), and how the benefits of the port industry are spread within the regional economy and port activity compared with other sectors of the economy.

\section{METHODOLOGY, DATA COLLECTION, RESULTS, AND DISCUSSION}

\subsection{Methodology and Data Collection}

As underlined by Sánchez and Moreno (2016), and PWC (2017), although there is a significant number of works using the IOM in EIAPs, all these studies are not directly comparable for different reasons. Among the main reasons that the authors emphasized are the following: 1) differences in geographical scope; 2) time base and horizon in which the studies are developed; 3) methodological divergences and dissimilar assumptions; 4) different indices and results provided; 5) considerations related to definition of the groups of impacts (port and port-dependent industries) that are taken into account on the model; 6) differences about the date of reference regarding the production and employment multipliers; 7) inclusion or exclusion of the investments as an additional element of the EIAP; 8) different level of aggregation of specific sectors.

Made this proviso and with the precautions to be taken when conducting comparative studies, a first compilation study of interest is found in Rodríguez-Dapena (2005), who analyzed the results of the impact in a set of twenty Spanish ports in the period 1992-2001. The author analyzed two indices, namely the GVA ${ }_{m p}$ and the employment generated. These indices were analyzed dually, first considering the port sector itself, and then taking into account also the economy dependent on port activity.

Since then, new studies have been presented, analytical techniques have been purified and efforts have been made to converge methodologies by facilitating the analysis. In this paper, update on the latter valuable author's study has been carried out completing the analysis in the following line:

- Forty studies have been reviewed in this paper ( the number of previous reviews doubled).

- The number of comparative parameters has also been increased. A new productivity ratio is added (employment to $\mathrm{GVA}_{\mathrm{mp}}$ ratio expressed in $€$ /employment), keeping the other two classic indices under consideration (i.e. traffic to $\mathrm{GVA}_{\mathrm{mp}}$ ratio expressed in $€ /$ tn and traffic to employment ratio expressed in employment/tn).

- The economic values of the different studies have been updated to the last year with available data (2016), using as deflector coefficient the variation of the GDP between the year in which the study is carried out and that year.

- The impact introduced by the port traffic structure has been analyzed using as a comparison the percentage of general merchandise of the port (concerning total traffic).

- A new comparative analysis has been made using the results obtained in this sample base and those results offered for other environments out of Spain, based on the meta-Study of OECD (2014). This work, international in nature, analyzed more than 150 EIAPs.

The sources of data used in this paper (Table 1) are the following:

- $\quad$ EIAPs covering the SPP before 2001, the results provided in Rodríguez-Dapena (2005).

- $\quad$ EIAPs covering the SPP after 2001, EIAPs provided by Port Authorities or publicly available.

- The deflector coefficient has been extracted from the online database provided by the Instituto Nacional de Estadística (hereafter, INE) dependent on the Ministry of Finance.

- Port traffic data for the year 2000 has been obtained from the Annual Reports of Port Authorities available on EPPE (2018a). - Port traffic until the year 2000 has been obtained from the historical database of port traffic available on EPPE (2018b). 
Table 1.

Port Traffic and Economic Impact on the SPS.

\begin{tabular}{|c|c|c|c|c|c|c|c|c|c|}
\hline \multirow[t]{2}{*}{ Port } & \multirow[t]{2}{*}{ Year } & \multirow{2}{*}{$\begin{array}{l}\text { Total Port } \\
\text { Traffic } \\
\text { (103 tons) }\end{array}$} & \multirow{2}{*}{$\begin{array}{l}\text { General } \\
\text { Cargo } \\
\text { (103tons) }\end{array}$} & \multirow{2}{*}{$\begin{array}{l}\text { \% General } \\
\text { Cargo }\end{array}$} & \multirow{2}{*}{$\begin{array}{l}\text { Deflector } \\
\text { coefficient }\end{array}$} & \multicolumn{2}{|c|}{ GVAmp (thousands of $€$ ) } & \multicolumn{2}{|c|}{ Employment } \\
\hline & & & & & & $\begin{array}{l}\text { Port } \\
\text { Industry }\end{array}$ & $\begin{array}{l}\text { Economy } \\
\text { dependent }\end{array}$ & $\begin{array}{l}\text { Port } \\
\text { Industry }\end{array}$ & $\begin{array}{l}\text { Economy } \\
\text { dependent }\end{array}$ \\
\hline Galicia & 1992 & 22,991 & 2,544 & $11 \%$ & 1.620580 & 191 & 2,377 & 6,514 & 112,771 \\
\hline $\begin{array}{l}\text { La Luz y las } \\
\text { palmas }\end{array}$ & 1992 & 9,728 & 4,129 & $42 \%$ & 1.620580 & 221 & - & 5,816 & - \\
\hline Santander & 1992 & 3,812 & 682 & $18 \%$ & 1.620580 & 91 & 805 & 3,601 & 28,935 \\
\hline $\begin{array}{l}\text { Sta. Cruz } \\
\text { de Tenerife }\end{array}$ & 1992 & 12,632 & 3,670 & $29 \%$ & 1.620580 & 144 & - & 4,147 & - \\
\hline Avilés & 1995 & 4,099 & 1,346 & $33 \%$ & 1.556436 & 115 & 376 & 2,484 & 7,865 \\
\hline Barcelona & 1995 & 23,292 & 9,401 & $40 \%$ & 1.556436 & 807 & - & 16,104 & - \\
\hline Gijón & 1995 & 21,791 & 489 & $2 \%$ & 1.556436 & 308 & 815 & 4,625 & 17,984 \\
\hline Sevilla & 1995 & 3,574 & 916 & $26 \%$ & 1.556436 & 28 & 428 & 1,849 & 15,069 \\
\hline Tarragona & 1995 & 28,705 & 749 & $3 \%$ & 1.556436 & 209 & - & 3,259 & - \\
\hline $\begin{array}{l}\text { Bahía de } \\
\text { Algeciras }\end{array}$ & 1996 & 36,836 & 16,560 & $45 \%$ & 1.515889 & 331 & 1,500 & 10,609 & 37,569 \\
\hline Ceuta & 1996 & 3,094 & 465 & $15 \%$ & 1.515889 & 25 & 106 & 1,588 & 3,983 \\
\hline Castellón & 1997 & 8,382 & 641 & $8 \%$ & 1.461949 & 114 & 354 & 2,458 & 6,277 \\
\hline $\begin{array}{l}\text { Bahía de } \\
\text { Cádiz }\end{array}$ & 1998 & 4,007 & 2,359 & $59 \%$ & 1.401597 & 64 & 633 & 1,642 & 15,620 \\
\hline Santander & 1998 & 4,949 & 1,112 & $22 \%$ & 1.401597 & 133 & 2,034 & 3,114 & 25,630 \\
\hline Bilbao & 1999 & 27,056 & 7,317 & $27 \%$ & 1.341436 & 392 & - & 9,792 & - \\
\hline Avilés & 2000 & 4,138 & 1,095 & $26 \%$ & 1.274050 & 178 & 516 & 2,078 & 8,230 \\
\hline Barcelona & 2000 & 30,160 & 17,585 & $58 \%$ & 1.274050 & 1,011 & - & 16,084 & - \\
\hline Cartagena & 2000 & 17,349 & 481 & $3 \%$ & 1.274050 & 64 & 340 & 1,525 & 8,796 \\
\hline Gijón & 2000 & 19,807 & 616 & $3 \%$ & 1.274050 & 153 & 1,237 & 2,779 & 20,551 \\
\hline Sevilla & 2000 & 4,492 & 1,522 & $34 \%$ & 1.274050 & - & - & 3,981 & 12,327 \\
\hline Marín & 2001 & 1,906 & 938 & $49 \%$ & 1.225036 & 52 & 108 & 2,154 & 4,574 \\
\hline Pasajes & 2001 & 4,720 & 1,673 & $35 \%$ & 1.225036 & 136 & 522 & 1,699 & 20,674 \\
\hline Vigo & 2001 & 4,112 & 2,950 & $72 \%$ & 1.225036 & 148 & 454 & 3,945 & 17,999 \\
\hline Villagarcía & 2001 & 1,025 & 268 & $26 \%$ & 1.225036 & 13 & 22 & 234 & 650 \\
\hline Algeciras & 2003 & 56,761 & 32,370 & $57 \%$ & 1.153961 & 155 & 234 & 2,294 & 4,852 \\
\hline Málaga & 2003 & 2,286 & 368 & $16 \%$ & 1.153961 & 83 & - & 1,757 & - \\
\hline Castellón & 2004 & 11,443 & 977 & $9 \%$ & 1.118539 & - & 125 & 558 & 2,662 \\
\hline Las Palmas & 2005 & 24,937 & 16,203 & $65 \%$ & 1.078391 & 305 & 578 & 4,597 & 9,475 \\
\hline Santander & 2005 & 6,701 & 1,220 & $18 \%$ & 1.078391 & 240 & 619 & 2,548 & 11,465 \\
\hline Alicante & 2009 & 2,511 & 1,260 & $50 \%$ & 1.023119 & 18 & 39 & 316 & 770 \\
\hline Almería & 2009 & 3,958 & 543 & $14 \%$ & 1.023119 & 24 & 53 & 381 & 952 \\
\hline
\end{tabular}




\begin{tabular}{llllllllll}
\hline Ferrol & 2009 & 4,960 & 445 & $9 \%$ & 1.023119 & 93 & 165 & 1,773 & 3,982 \\
\hline Bilbao & 2010 & 34,665 & 9,446 & $27 \%$ & 1.022975 & - & - & 5,100 & 12,500 \\
\hline Cádiz & 2010 & 4,005 & 2,042 & $51 \%$ & 1.022975 & 278 & 534 & 4,366 & 10,275 \\
\hline Huelva & 2010 & 22,283 & 283 & $1 \%$ & 1.022975 & 685 & 1,353 & 3,017 & 15,253 \\
\hline Baleares & 2011 & 11,199 & 7,985 & $71 \%$ & 1.033296 & 701 & 1,264 & 13,949 & 25,539 \\
\hline Cartagena & 2011 & 22,734 & 1,139 & $5 \%$ & 1.033296 & 465 & 986 & 2,318 & 11,726 \\
\hline Algeciras & 2014 & 94,935 & 61,183 & $64 \%$ & 1.068191 & 1,136 & 1,857 & 9,726 & 25,066 \\
\hline $\begin{array}{l}\text { Puertos de } \\
\text { Andalusia }\end{array}$ & 2014 & 139,704 & 67,702 & $48 \%$ & 1.068191 & 3,090 & 5,695 & 26,253 & 86,061 \\
\hline Castellón & 2015 & 16,474 & 3,154 & $19 \%$ & 1.032745 & - & 319 & 2,178 & 6,048 \\
\hline Valencia & 2015 & 70,081 & 63,102 & $90 \%$ & 1.032745 & 1,745 & 2,352 & 25,399 & 36,978 \\
\hline & & & & & & &
\end{tabular}

The results obtained for the selected productivity indicators are presented in Table 2, updated to 2016.

Table 2.

Productivity Ratios of EIAPs in the SPS (updated to 2016).

\begin{tabular}{|c|c|c|c|c|c|c|}
\hline \multirow[t]{2}{*}{ Port } & \multicolumn{3}{|l|}{ Port Industry } & \multicolumn{3}{|c|}{ Economy Dependent } \\
\hline & $\mathrm{GVA}_{\mathrm{mp}}(€) / \mathrm{tn}$ & $\begin{array}{l}\text { Employment / } \\
10^{6} \mathrm{tn}\end{array}$ & $\begin{array}{l}\mathrm{GVA}_{m p}(€) / \\
\text { employment }\end{array}$ & $\mathrm{GVA}_{\mathrm{mp}}(€) / \mathrm{tn}$ & $\begin{array}{l}\text { Employment / } \\
10^{6} \mathrm{tn}\end{array}$ & $\begin{array}{l}\text { GVA }_{m p}(€) / \\
\text { employment }\end{array}$ \\
\hline Galicia & 13.5 & 283 & 47,518 & 167.5 & 4,905 & 34,159 \\
\hline $\begin{array}{l}\text { La Luz y las } \\
\text { palmas }\end{array}$ & 36.8 & 598 & 61,580 & - & - & - \\
\hline Santander & 38.7 & 945 & 40,953 & 342.2 & 7,591 & 45,086 \\
\hline $\begin{array}{l}\text { Sta.Cruz de } \\
\text { Tenerife }\end{array}$ & 18.5 & 328 & 56,273 & - & - & - \\
\hline Avilés & 43.7 & 606 & 72,057 & 142.8 & 1,919 & 74,408 \\
\hline Barcelona & 53.9 & 691 & 77,996 & - & - & - \\
\hline Gijón & 22.0 & 212 & 103,650 & 58.2 & 825 & 70,535 \\
\hline Sevilla & 12.2 & 517 & 23,570 & 186.4 & 4,216 & 44,207 \\
\hline Tarragona & 11.3 & 114 & 99,814 & - & - & - \\
\hline $\begin{array}{l}\text { Bahía de } \\
\text { Algeciras }\end{array}$ & 13.6 & 288 & 47,296 & 61.7 & 1,020 & 60,524 \\
\hline Ceuta & 12.2 & 513 & 23,865 & 51.9 & 1,287 & 40,343 \\
\hline Castellón & 19.9 & 293 & 67,804 & 61.7 & 749 & 82,449 \\
\hline Bahía de Cádiz & 22.4 & 410 & 54,630 & 221.4 & 3,898 & 56,800 \\
\hline Santander & 37.7 & 629 & 59,863 & 576.0 & 5,179 & 111,231 \\
\hline Bilbao & 19.4 & 362 & 53,701 & - & - & - \\
\hline Avilés & 54.8 & 502 & 109,134 & 158.9 & 1,989 & 79,880 \\
\hline Barcelona & 42.7 & 533 & 80,084 & - & - & - \\
\hline
\end{tabular}




\begin{tabular}{|c|c|c|c|c|c|c|}
\hline Cartagena & 4.7 & 88 & 53,468 & 25.0 & 507 & 49,247 \\
\hline Gijón & 9.8 & 140 & 70,144 & 79.6 & 1,038 & 76,687 \\
\hline Sevilla & - & 886 & - & - & 2,744 & - \\
\hline Marín & 33.4 & 1130 & 29,574 & 69.4 & 2,400 & 28,925 \\
\hline Pasajes & 35.3 & 360 & 98,061 & 135.5 & 4,380 & 30,931 \\
\hline Vigo & 44.1 & 959 & 45,958 & 135.3 & 4,377 & 30,900 \\
\hline Villagarcía & 15.5 & 228 & 68,058 & 26.3 & 634 & 41,463 \\
\hline Algeciras & 3.2 & 40 & 77,970 & 4.8 & 85 & 55,653 \\
\hline Málaga & 41.9 & 769 & 54,513 & - & - & - \\
\hline Castellón & - & 49 & - & 12.2 & 233 & 52,523 \\
\hline Las Palmas & 13.2 & 184 & 71,549 & 25.0 & 380 & 65,785 \\
\hline Santander & 38.6 & 380 & 101,575 & 99.6 & 1,711 & 58,223 \\
\hline Alicante & 7.3 & 126 & 58,279 & 15.9 & 307 & 51,820 \\
\hline Almería & 6.3 & 96 & 65,093 & 13.8 & 241 & 57,380 \\
\hline Ferrol & 19.1 & 357 & 53,420 & 34.0 & 803 & 42,340 \\
\hline Bilbao & - & 147 & - & - & 361 & - \\
\hline Cádiz & 71.0 & 1090 & 65,137 & 136.4 & 2,565 & 53,165 \\
\hline Huelva & 31.4 & 135 & 232,263 & 62.1 & 685 & 90,742 \\
\hline Baleares & 64.7 & 1246 & 51,908 & 116.7 & 2,280 & 51,160 \\
\hline Cartagena & 21.1 & 102 & 207,283 & 44.8 & 516 & 86,886 \\
\hline Algeciras & 12.8 & 102 & 124,765 & 20.9 & 264 & 79,136 \\
\hline $\begin{array}{l}\text { Puertos de } \\
\text { Andalusia }\end{array}$ & 23.6 & 188 & 125,727 & 43.5 & 616 & 70,686 \\
\hline Castellón & - & 132 & - & 20.0 & 367 & 54,472 \\
\hline Valencia & 25.7 & 362 & 70,953 & 34.7 & 528 & 65,688 \\
\hline
\end{tabular}

\subsection{Results and Discussion}

With the set of reports analyzed, the following findings can be emphasized:

The GVA per ton presents an average of $27 € /$ tn for the port sector and about $100 € /$ tn for the dependent economy, but with wide ranges of variation reaching the maximums of $71 € /$ th (port industry) and $576 € /$ tn (economy dependent), and the minimums of $3 € /$ tn (port industry) and $5 € /$ tn (dependent economy) (Table $3)$.

It should be noted that with regard to this indicator OECD (2014) set that: i) the larger a port, the greater its capacity to generate GVA and, ii) on average, each ton moved by a port generated 100 USD of GVA with 2/3 of the ports in the range 50$250 \$ / \mathrm{tn}$, but with the largest ports placed in the uppermost part of this range. However, this comparison has to be taken prudently since OECD (2014) evaluates only direct and indirect impacts.
In terms of employment generation, average values reach 418 jobs per million tons (port industry) and 1,812 jobs per million tons (dependent economy) with the maximums of 1,246 and 7,591 respectively, and the minimums of 40 and 85 (Table 3).

In terms of productivity, each job in the port sector has an average capacity to generate a value of $75,824 €$ within the port industry and 59,170 $€$ throughout the dependent economy. This figure oscillates in the maximum ranges of up to $232,263 €$ and the minimum of up to $23,570 €$ (Table 3 ).

One relevant conclusion is that the port industry usually has higher productivity in terms of GVA $\mathrm{mp}_{\mathrm{m}}(€) /$ employment than its dependent economy.

There is no doubt that this wide dispersion of results could be found mainly in the aspects already emphasized by Sánchez and Moreno (2016) and PWC (2017) as well as the different sizes and locations of the ports included in the SPS. 
Table 3.

Summary of conclusions regarding EIAPs within the SPS.

\begin{tabular}{|c|c|c|c|c|c|c|}
\hline & \multicolumn{3}{|l|}{ Port Industry } & \multicolumn{3}{|c|}{ Economy Dependent } \\
\hline & $\mathrm{GVA}_{\mathrm{mp}}(€) / \mathrm{tn}$ & $\begin{array}{l}\text { Employment / } \\
10^{6} \mathrm{tn}\end{array}$ & $\begin{array}{l}\mathrm{GVA}_{\mathrm{mp}}(€) / \\
\text { employment }\end{array}$ & $\mathrm{GVA}_{\mathrm{mp}}(€) / \mathrm{tn}$ & $\begin{array}{l}\text { Employment } \\
/ 10^{6} \mathrm{tn}\end{array}$ & $\begin{array}{l}\mathrm{GVA}_{\mathrm{mp}}(€) / \\
\text { Employment }\end{array}$ \\
\hline AVERAGE & 27 & 418 & 75,824 & 100 & 1,812 & 59,170 \\
\hline MAX & 71 & 1,246 & 232,263 & 576 & 7,591 & 111,231 \\
\hline MIN & 3 & 40 & 23,570 & 5 & 85 & 28,925 \\
\hline
\end{tabular}

\section{CALCULATIONS AND WORK CONTRIBUTION}

Going further to the results by taking into consideration the special characteristics of each port, the following conclusions can be reached:

Consistent with the results of OECD (2014), a linear relationship between the capacity to generate GVA and the size of a port can be established in the SPS using the following formulae:

$\mathrm{GVA}_{\mathrm{mp}}=0.0181 \times$ traffic +2.7035 (port industry) (Figure 1),

$\mathrm{GVA}_{\mathrm{mp}}=0.0293 \times$ traffic +296.49 (economy dependent on the port industry) (Figure 2),

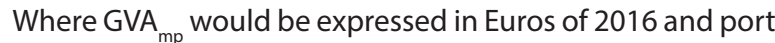
traffic should be expressed in thousands of tons.

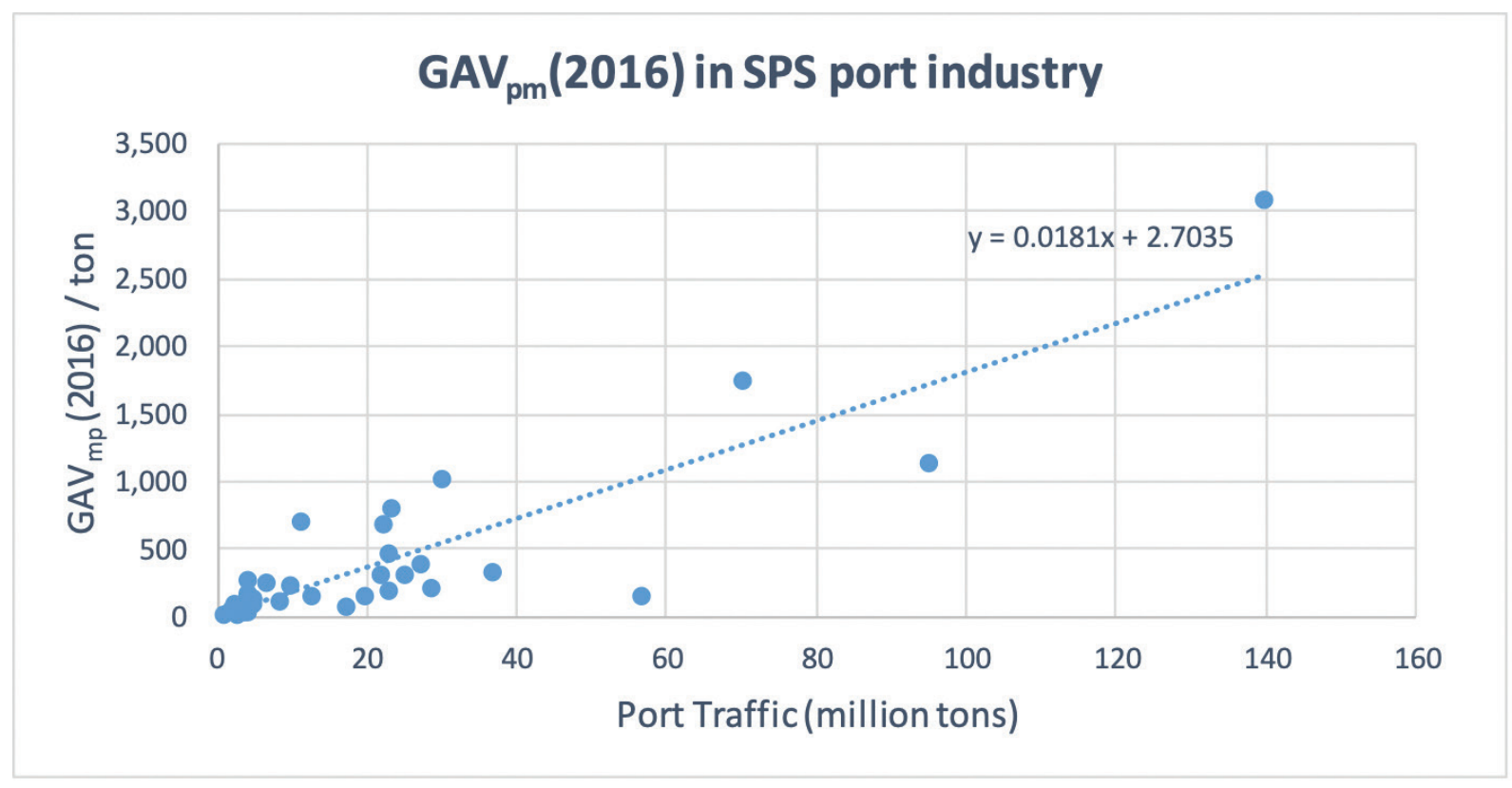

Figure 1.

GVA $_{m p}$ (2016) in SPS port industry vs Port Traffic. 


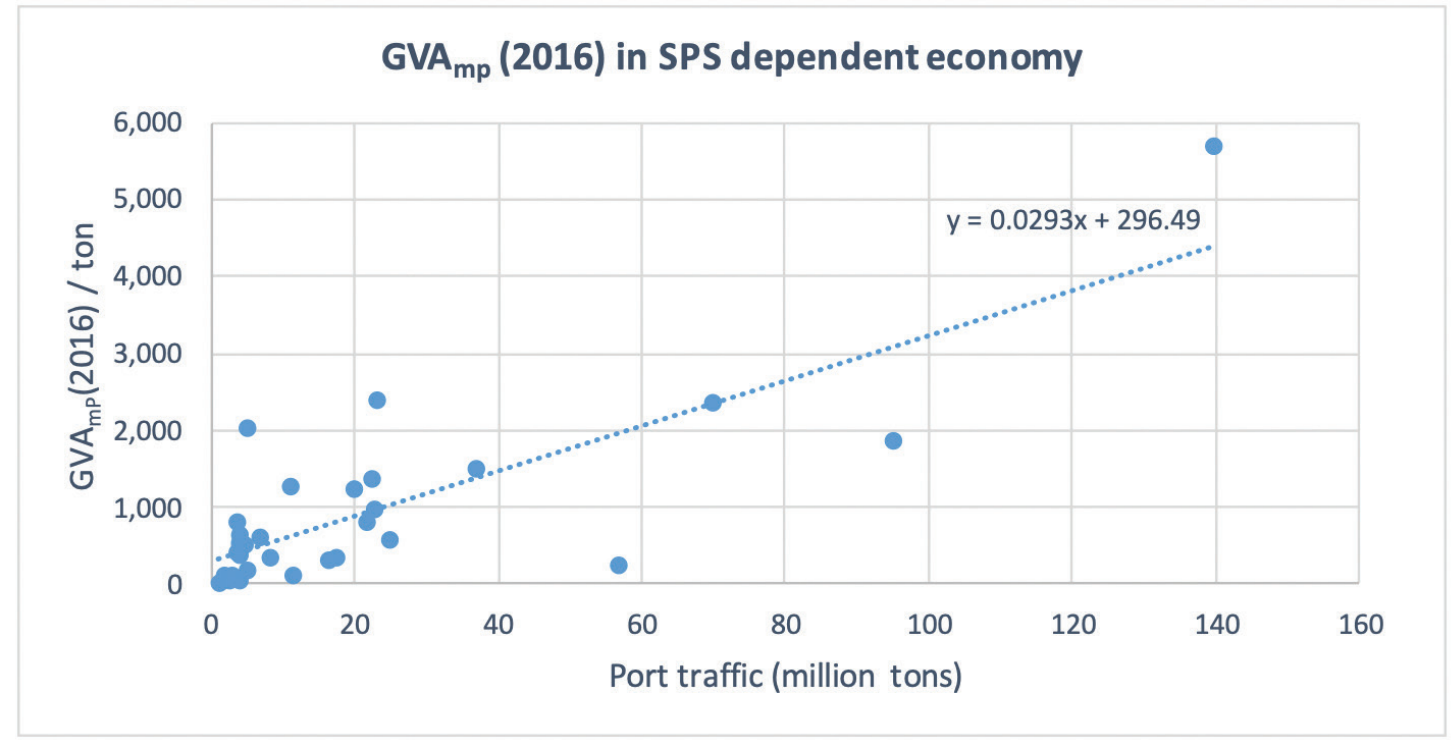

Figure 2.

GVA $_{m p}$ (2016) in SPS dependent economy vs. port traffic.

It seems that the opposite effect is obtained in which the larger port size derives from a lower unitary capacity to generate employment and thus in a lower job/ton ratio (Figure 3) However, the relationship between the capacity to generate employment and structure of the traffic in a port can be observed in such a way that ports with more general cargo require a greater number of jobs, something that is already known and is perceived in an intuitive way (Figure 4).

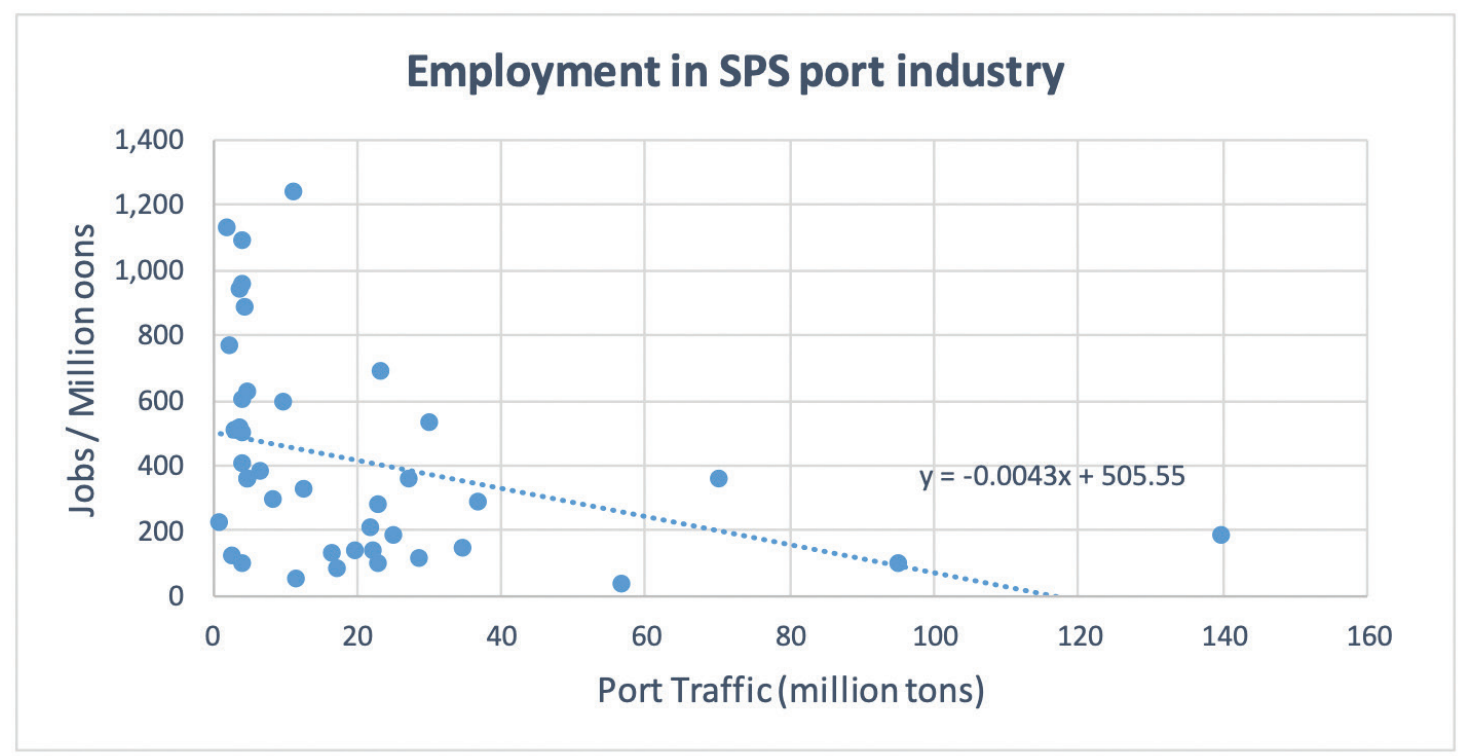

Figure 3.

Employment in SPS port industry vs. port traffic. 


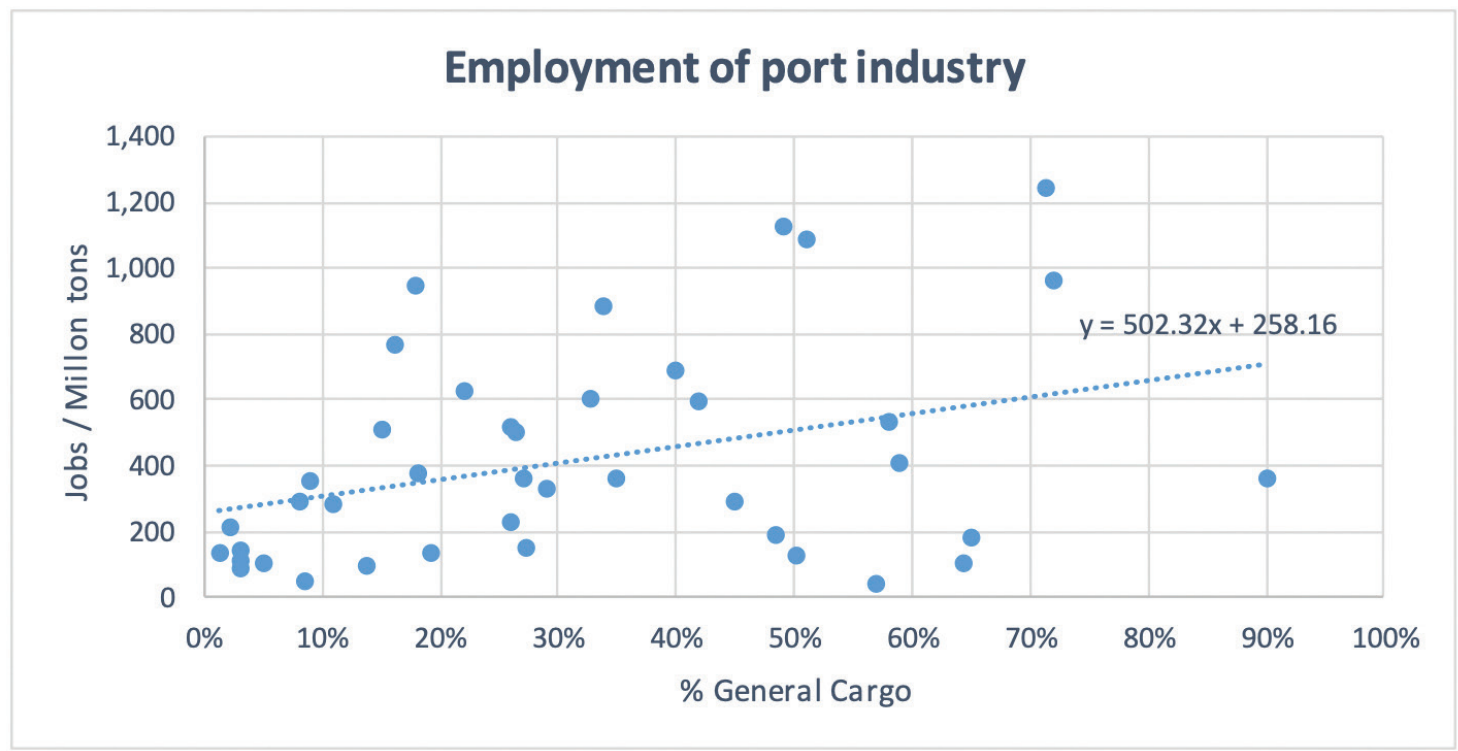

Figure 4.

Employment of port industry vs. percentage of general cargo.

There is a relationship between the capacity to generate GVA per employment in the port sector and the size of the port. The ports handling more tons create more economic value per job (Figure 5). This is attributed mainly to the higher efficiency and productivity of a larger port versus smaller ones.

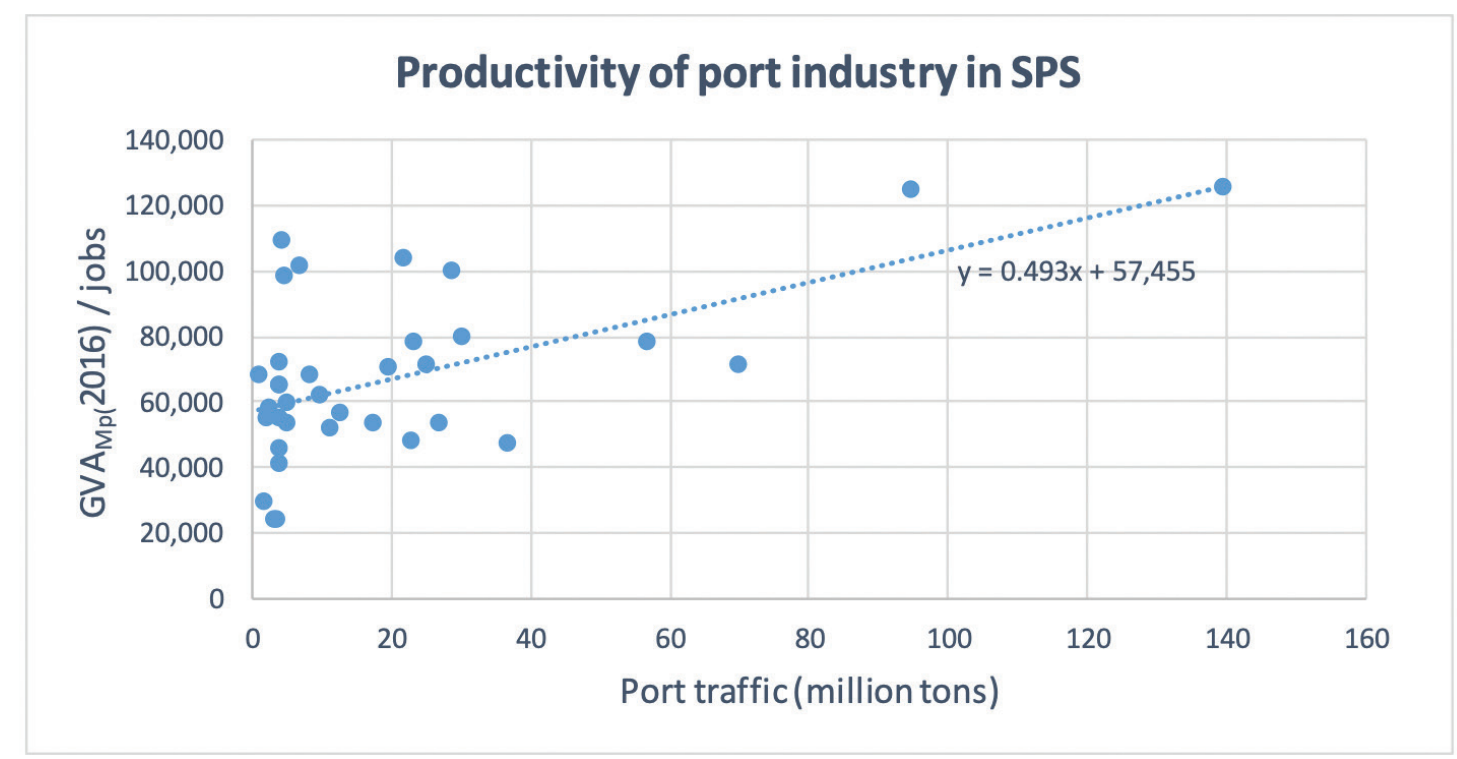

Figure 5.

Productivity of the port industry in SPS vs. port traffic. 
However, there is no statistical significance between port productivity (GVA/job) and the traffic structure ( $\%$ general cargo) (Figure 6). Related to this index, the results are more homogeneous, and $70 \%$ of the ports are located in the range $40,000-80,000 € /$ job with only $9 \%$ below $40,000 € /$ job and $20 \%$ above $80,000 € /$ job.

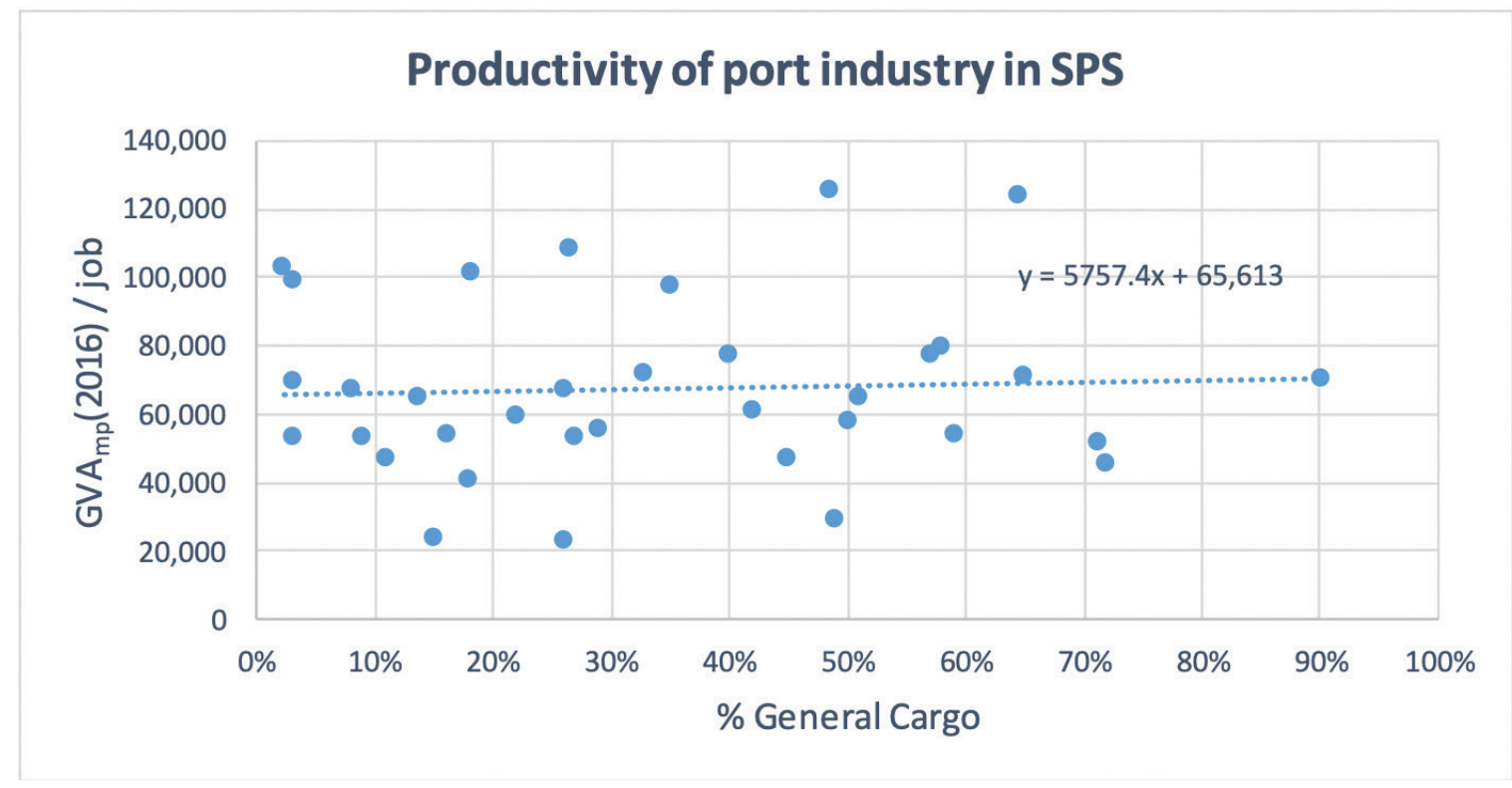

Figure 6.

The productivity of the port industry in SPS vs. structure of cargo.

\section{CONCLUSIONS}

After more than 60 years of evolution, there is a large number of studies addressing the economic impact assessment of ports. The approach in these reports is technical or commercial in nature, and most of them do not provide a scientific approach using self-criticism or providing an in-depth analysis of the methodology used. They usually do not present their limitations or discuss extensively their results from the scientific point of view. Therefore, there is a lack of comparative analysis among different ports. They present their results in an isolated manner without proper benchmarking.

When benchmarking is applied over a set of 40 studies within the Spanish Port System, it is found that there is a relationship between the size of a port and its GAC, the number of jobs it generates. This is not only in absolute terms (which is very intuitive), but also in relative terms (\$/ton or employment/ton). There is also a relationship between the capacity to generate GVA per employment in the port sector and the size of the port. The ports handling more tons create more economic value per job.

The above-mentioned outcomes can be attributed mainly to higher efficiency and productivity of a larger port versus smaller ones.

\section{FUTURE RESEARCH AREAS}

For future research, the following areas of special interest are suggested:

firstly, to analyze if there have been significant changes in the results and indicators between the oldest and the most recent studies as a result of either the methodological aspect or due to the technological evolution and increase in the productivity of the ports;

secondly, to determine the influence of port size and traffic structure by analyzing a set of ports segmentally, trying to draw conclusions between ports of similar size and/or similar traffic composition;

thirdly, to carry out additional in-depth studies of Port Economic Assessments in other contexts and jurisdictions, to determine if there is a geographical influence and, if so, to provide potential explanations for it.

\section{REFERENCES}

Acosta, M., Coronado, D., and Cerbán, M.M., 2009a. Evaluación del impacto económico del puerto de Tarifa: Situación actual y prospectiva tras la ampliación. Department of Economy, University of Cádiz, Cadiz, Spain. 
Acosta, M., Coronado, D., Cerbán, M.M., and López, P., 2009b. El proceso de contenerización en el Puerto Bahía de Algeciras. Tendencias globales e impacto económico regional. Revista de Estudios Regionales 84(1), pp. 167-201.

Acosta, M., Coronado, D., and Cerbán, M.M., 2016. Evaluación del impacto económico del puerto de la bahía de Cádiz 2014. Department of Economy, University of Cádiz.

Anderson, G.K., 1964. The port of Ensenada: A report on Economic Development. San Diego State College Foundation, Economics Research Center, California, USA.

APB, and CAEB., 2010. Aportación económica de los puertos del Estado en Baleares 2007. Baleares PA and Confederación de Asociaciones de Empresarios de Baleares, CAEB. Mallorca, Spain

Arta,I A., Gómez, J.M., Navarro, J.M., and Ramos, J.M., 2016. Estimating the economic impact of a port through regional input-output tables: Case study of the Port of Cartagena. Maritime Economics \& Logistics 18(4), pp. 371-390.

Aza, R., Baños, J., Lago, J.A., and Canal, J., 2000. El impacto del puerto de Gijón sobre la economía del Principado de Asturias. Municipality of Gijón, Gijón, Spain.

Aza, R., and Baños, J., 2003. Estudio de impacto económico sobre la economía portuaria asturiana. University of Oviedo and University of Cantabria, Oviedo, Spain.

Aza, R., Baños, J., Lago, J.A., and Canal, J., 2004. El impacto de la inversión en infraestructuras portuarias sobre el producto regional. El caso de la Ampliación del puerto de Gijón. University of Oviedo, Asturias, Spain.

Bernal, J.J., and García, A., 2003. El Puerto de Cartagena. Análisis de impacto sobre la economía comarcal y regional. Ed. Civitas, Navarra, Spain.

Bernal, J.J., and García, A., 2005. Impacto Económico del Puerto de Cartagena sobre la economía comarcal y regional: Un estudio de modelización y simulación. Proceedings of the XI Congreso de Tráfico Marítimo y Gestión Portuaria, Cartagena, Spain, pp. 233-240.

Bernaldo de Quirós, F., 2005. La experiencia acumulada en la realización de estudios de impacto económico en los puertos españoles. Proceedings of the XI Congreso de Tráfico Marítimo y Gestión Portuaria, Cartagena, Spain, pp. 263-270.

Bilbao Plaza Marítima, 1995. Estudio del impacto económico del Puerto de Bilbao en el País Vasco. Department of Transport and Public Works, Regional Government of the Basque Country, Bilbao, Spain.

Bilbao Plaza Marítima, 1998. Impacto Económico del puerto de Marín en Galicia y la provincia de Pontevedra. Marín-Pontevedra PA and EPPE, Pontevedra, Spain.

Canal, J., Aza, R., Baños, J., and Lago J., 2001. El impacto del Puerto de Gijón sobre la economía del Principado de Asturias. Gijón PA, Gijón, Spain.

Castillo, J.I., López, L., and Aracil, M.J., 2003a. El impacto económico del Puerto de Sevilla sobre la economía de la provincia de Sevilla para el año 2000. Estudio integral de la actividad portuaria en provincia de Sevilla, Ed. Pirámide, Madrid, Spain.

Castillo, J.I., López, L., and Aracil, M.J., 2003b. La incidencia de la inversión pública en el impacto económico de la actividad portuaria a través de un modelo de simulación dinámica: Aplicación práctica al puerto de Sevilla. Proceedings of the XXIX Reunión de Estudios Regionales, Santander, Spain, pp.1-20.

Castillo J.I., Coto, P., Pesquera, M.A., and López, L., 2004. Comparative Analysis of Port Economic Impact Studies in the Spanish Port System, 1992-2000). In: Coto, P (Ed). Essays on Microeconomics and Industrial Organization. Phisica-Verlag Heidelberg, Springer. New York, USA, pp. 297-316.

Castillo, J.I., 2005. Aplicaciones prácticas de los estudios de impacto económico: Bahía de Algeciras, Sevilla y Ceuta. Proceedings of the XI Congreso de Tráfico Marítimo y Gestión Portuaria, Cartagena, Spain, pp. 279-288.
Castillo, J.I., López, L., and Aracil, M.J., 2007. Dynamising Economic Impact Studies: the Case of the Port of Seville. In: Coto, P, Inglada, V (Eds), Essays on Transport Economics, Phisica-Verlag Heidelberg, Springer, New York, USA, pp. 183-216.

Castillo J.I., and López, L., 2012. Los Estudios de impacto económico portuarios: ¿es el mejor instrumento de relaciones públicas o el heraldo de la sobreinversión? Papeles de Economía Española 131(1), pp. 200-208.

CEET., 2009. Impacto Económico del Puerto de Alicante. Año 2007. Centro de Estudios Económicos Tomillo and EPPE, Alicante, Spain.

Chang, S., 1978. In Defense of Port Economic Impact Studies. Transportation Journal 17(3), pp. 79-85.

CONSULTRANS and CEET, 1998. Análisis de impacto económico de los Puertos de Barcelona y Tarragona. CONSULTRANS, CEET and EPPE, Barcelona, Spain.

CONSULTRANS., 2008a. Estudio de Impacto Económico del Puerto de Castellón. EPPE. Castellón de la Plana, Spain.

CONSULTRANS., 2008b. Estudio de Impacto Económico del Puerto de Ferrol. EPPE, Ferrol, Spain.

Coronado, D., Acosta, M., Cerbán, M.M., and Moreno, P.J., 2009. Evaluación del impacto económico del Puerto de la Bahía de Cádiz 2008. Puertos 149(1), pp. 5-13

Coronado, D., Acosta, M, Cerbán, M.M., and Moreno, P.J., 2012. Evaluación del impacto económico del puerto Bahía de Algeciras. Ed. Civitas. Madrid, Spain.

Coronado, D., Acosta, M., and Cerbán, M.M., 2016. Evaluación del impacto económico del puerto Bahía de Algeciras. Bahía Algeciras PA and University of Cádiz, Cádiz, Spain.

Coto, P., and Martínez, E., 1995. Contribución a la economía española del sector portuario. Boletín económico de ICE, Información Comercial Española, 2460-2461, pp. 43-50.

Coto, P., Mateo, I., and Villaverde, J., 2010a. The economic impact of ports: its importance for the region and also the hinterland. In: Coto, P, Pesquera, M.A Castanedo, J (Eds), Essays on Port Economics, Springer-Verlag Berlin Heidelberg, pp. $167-200$

Coto, P., Mateo, I., and Villaverde, J., 2010b. A methodological discussion on port economic impact studies and their possible applications to policy design. In: Coto, $\mathrm{P}$ Pesquera, M.A, Castanedo, J (Eds), Essays on Port Economics, Springer-Verlag Berlin Heidelberg, pp. 151-160.

Deloitte, 2016. Contribución socio-económica del puerto de Bilbao. Bilbao PA, Bilbao, Spain.

De Rus, G., Román, C., and Trujillo, L., 1994. Actividad económica y estructura de costes del Puerto de La Luz y de las Palmas. Revista Asturiana de Economía, 3(1995), pp. 81-103.

De Rus, G., González, M.M., and Tovar, B., 2007. Impacto económico del Puerto de Las Palmas. Technical Report. Department of Applied Economic Analysis, Faculty of Business and Economic Sciences. University of las Palmas de Gran Canaria. Las Palmas, Spain.

De Rus, G., Tovar, B., and González, M.M., 2009. Impacto económico del Puerto de Las Palmas. Colección Economía. Ed. Cívitas, Navarra, Spain.

De Rus, G., Betancor, O., Campos, C., Eugenio, J.L., Socorro, P., Matas, A., Raymond, J.L., González, M., Brey, P., Nombela, G., and Benavides, J., 2010. Evaluación Económica de proyectos de transporte. Centro de Experimentación de Obras Públicas - CEDEX, Madrid, Spain. 
De Rus, G., Betancor, O., Campos, C., Eugenio, J.L., Socorro, P., Matas, A., Raymond, J.L., González, M., Brey, P., Nombela, G., and Benavides, J., 2010b. Evaluación Socioeconómica de la Ampliación del Puerto de Sagunto: construcción de la Dársena 2. Centro de Experimentación de Obras Públicas - CEDEX, Madrid, Spain.

De Rus, G., and Betancor, O., 2012. Análisis coste-beneficio de proyectos portuarios. ["Cost-benefit analysis of port projects"]. Papeles de Economía Española 131(2012), pp. 93-105.

EPPE., 1996. Impacto Económico de la expansión del puerto de Bahía de Algeciras. Eds. Bahía de Algeciras PA and EPPE, Algeciras, Spain.

EPPE., 2018a. Anuarios Estadísticos., Statistical Annals. Available at: http://www. puertos.es/es-es/estadisticas/RestoEstadísticas/Paginas/Resto-estadisticas.aspx.

EPPE., 2018b. Estadística Histórica desde 1962., Statistical Annals from 1962. Available at: http://www.puertos.es/es-es/estadisticas/Paginas/estadistica Historicas.aspx.

Fernández-Márquez, M., 2007. Estudio sobre el impacto económico del Puerto de Motril. Motril PA and ESACA, Almería, Spain.

Fernández, M., 2010. Impacto del puerto de Avilés sobre la economía del Principado de Asturias: 1995-2005. Ed. Civitas, Madrid, Spain.

Fraga, J., and Seijas, J.A., 1992. El Puerto de Ferrol y su influencia en la economía de la comarca. Junta del Puerto y Ría de Ferrol (Ed), Ferrol, Spain.

García del Hoyo, J.J., González, D., García, F., and de Paz, M., 1999. Estimación de los Efectos Económicos derivados de la Actividad del Puerto de Huelva. Huelva PA Fundación el Monte, University of Huelva and EPPE (eds), Huelva, Spain.

Guarnido, A., Sánchez, A., and Amate, I., 2010. Estudio de impacto económico del Puerto de Almería. Department of Applied Economy, University of Almería, Almería, Spain.

Hille, S.J., and Suelflow, J.E., 1969. The economic impact of the Port of Baltimore on Maryland's Economy. Proceedings of the 11th Annual Meeting of the Transportation Research Forum, New Orleans (USA), pp. 307-325.

Jaén, M., Fernández, F., de Pablo, J., Amate, I., Piedra, L., and Acién, E., 2001. El impacto económico del puerto de Almería sobre la economía almeriense y andaluza. University of Almería and Almería PA, Almería, Spain.

KPMG., 2000. El Impacto Económico del Puerto de Bilbao. Puertos 80 (2000), pp. 4-8.

Lago, J.A., 2005. Los estudios de impacto económico en el puerto de Gijón. Proceedings of the XI Congreso de Tráfico Marítimo y Gestión Portuaria, Cartagena, Spain, pp. 271-278.

Lebón, C., Castillo, J.I., and López, L., 1998. El impacto económico del Puerto de Sevilla sobre la economía andaluza. Ed. Civitas, Seville, Spain.

Leontief, W., 1966. Input-Output Economics. Oxford University Press, New York, USA.

Little, A.D. Inc., 1979. Port Economic Impact Kit. Washington. Dept. of Commerce, Maritime Administration, Office of Commercial Development, Office of Port and Intermodal Development, Washigton DC, USA.

Lloveras, M.D., 2005, Impacto Económico del Puerto de Barcelona. The economic impact of Barcelona Port. Proceedings of the XI Congreso de Tráfico Marítimo y Gestión Portuaria, Cartagena, Spain, pp. 233-240.

López, L., and Castro, M., 2001. El Puerto Bahía de Algeciras, el motor económico del Sur. Bahía de Algeciras PA. Cadiz, Spain.

MARAD., 1982. The Regional Port Impact Model Handbook. US Maritime Administration. Office of Port and Intermodal Development. Washington DC and New York and New Jersey PA, New York, USA.
MARAD, 1995. Economic Impact of the Port Industry on the New York - New Jersey Metropolitan Region. US Maritime Administration. Office of Economic and Policy Analysis New York and New Jersey PA, New York, USA.

Martí, M.L., Puertas, R., and Fernández, J.I., 2009. Metodología para el análisis del impacto portuario: aplicación a los Puertos de Gandía, Sagunto y Valencia. Ed. Fundación Valencia Port. Series Economía del Transporte, Valencia, Spain.

Martínez, E., 1993. Impacto Económico de los puertos. El sistema portuario español. PhD Thesis. University of la Laguna, Spain.

Martínez, E., 1996. Un estudio econométrico de los costes del sistema portuario español. Revista Asturiana de Economía, 5 (1996), pp. 135-150.

Martínez, E., Gutiérrez, P., López, L.J., and Martín, F.J., 1999. El impacto económico de los puertos de Santa Cruz de Tenerife sobre la provincia. Hacienda Pública Española, 148(1), pp. 175-185.

Mateo, I., and Coto, P., 2010. Impacto económico portuario por tipo de mercancía. Boletín Económico de ICE, 2998(1), pp. 43-51.

Mateo, I., Coto, P., Villaverde, J., and Pesquera, M.A., 2012. Economic impact of a port on the hinterland: application to Santander's port. International Journal of Shipping and Transport Logistics, 4(3), pp. 235-249.

Merk, O., and Notteboom, T., 2013. The Competitiveness of Global Port-Cities: The Case of Rotterdam/Amsterdam - the Netherlands. OECD Regional Development Working Paper 2013/8., Paris, France.

OECD., 2014. The Competitiveness of Global Port-Cities. Ed. Organization for Economic Co-operation and Development (OECD), Paris, France.

Parra, F., Ruiz, C., and lamnitchi, A.R., 2013. Impacto del tráfico del puerto de Santander en la economía de Cantabria. Proceedings of the XV Reunión de Economía Mundial, Santander, Spain, pp. 1-29.

Perea, J., and Gaona, A., 2007. El impacto económico de los puertos. Working Paper TYPSA, Madrid, Spain.

Pérez, J., and García, G., 2004. Ports economic impact: Literature review and alternative proposal. Journal of Maritime Research 1(3), pp. 85-104.

PWC., 2017. Impacto Socieconómico de los puertos comerciales de Andalucía. PriceWaterhouse-Coopers (Ed. Public Agency Ports of Andalusia), Seville, Spain.

Ramos, J.M., Navarro, J.M., and Artal, A., 2014. Estudio del Impacto Económico regional del puerto de Cartegena. Proceedings of the International Conference on Regional Science, Zaragoza, Spain.

Rey, J.M., Coronado, D., Acosta, M., Toribio, M.R., and Navarro, M.A., 2002. Evaluación del impacto económico del Puerto de la Bahía de Cádiz. Puertos 100(2002), pp. 19-22.

Rodríguez-Dapena, A., 2005. Una metodología para los estudios de impacto económico de la actividad portuaria. Proceedings of the XI Congreso de Tráfico Marítimo y Gestión Portuaria, pp. 233-262, Cartagena, Spain.

Rúa, M., Sastre, F., Castro, M., Alonso, T., and Tudurí, M., 2014. El Impacto Económico de los Puertos del Estado en Baleares - 2011 (Versión actualizada con datos del PIB 2013). Islas Baleares PA, Dep. Economy and Business, University of Islas Baleares and AEB, Palma de Mallorca, Spain.

Sánchez, C., and Moreno, A.J., 2016. Estudio de Impacto Económico del Puerto de Huelva 2016. Huelva PA, Huelva, Spain.

Schenker, E., 1965. Economic of a Port on Urban Community. Working Paper. Transportation Research Forum 1965. 
Schenker, E., 1967. The Port of Milwaukee. An economic review. University of Wisconsin, Milwaukee, USA

TEMA., 1994a. Elaboración de una metodología para la evaluación de los impactos de la actividad portuaria sobre la economía. Ed. EPPE; Madrid, Spain.

TEMA., 1994b. Evaluación de los Impactos de la Actividad de los Puertos de Galicia sobre la Economía de la Región. Ed. EPPE, Madrid, Spain.

TEMA., 1995. Evaluación de los Impactos de la Actividad de los Puertos de Galicia sobre la Economía Nacional. Ed. EPPE, Madrid, Spain.

Temple, Barker \& Sloane, Inc, Recht Hausrath \& Associates, Regional Science Research Institute., 1985. Port Economic Impact Kit. US Maritime Administration, Office of Port and Intermodal Development, Washington DC, USA.

Tinbergen, J., 1962. Shaping the World Economy: Suggestions for an International Economic Policy. The Twentieth Century Fund, New York, USA.

TYPSA., 1995. Estudio de Impacto Económico y Social del Puerto de Motril. AlmeríaMotril PA and EPPE, Almeria, Spain.

TYPSA., 2007. Estudio de Impacto Económico del Puerto de Málaga. Ed. EPPE, Madrid, Spain.

Universidad de Barcelona., 2014. Actividad de cruceros en Barcelona. Impacto sobre la economía catalana y perfil socioeconómico del crucerista (Resumen Ejecutivo). Ed. Barcelona PA and Barcelona Turisme.
UPV., 2017. Impacto Económico de los puertos de la Autoridad Portuaria de Valencia 2015. In: Valencia PA (ed), Department of Economy and Social Science - University of Valencia.

Vayá, E., García, J.R., Murillo, J., Romání, J., and Suriñach, J., 2016. Impacto económico de la actividad de cruceros: El caso del puerto de Barcelona. Proceedings of the XLII Meeting on Regional Studies- AECR. Santiago de Compostela, Spain, pp. 1-25.

Villaverde, J., and Coto, P., 1995. El impacto económico del Puerto de Santander en la economía cántabra. Santander PA and Cantabria Económica, Santander, Spain.

Villaverde, J., and Coto, P., 1996. Impacto económico portuario: Metodologías para su análisis y aplicación al Puerto de Santander. Santander PA and University of Santander, Santander, Spain.

Villaverde, J., and Coto, P., 1997. Economic Impact Analysis of Santander Port on its hinterland. International Journal of Transport Economics, 24(2), pp. 259-277.

Villaverde, J., and Coto, P., 1998. Port Economic Impact: methodologies and application to the Port of Santander. International Journal of Transport Economics, 25(2), pp. 159-179.

Villaverde J, Coto, P., Aza, R., Baños, J., and Canal J.F., 2003. Impacto de los puertos de Avilés y Gijón en la economía asturiana. Papeles de economía española 20(2003), pp. 207-219.

Waters, R.C., 1977. Port Economic Impact Studies: Practice and Assessment. Transportation Journal, 16(3), pp. 4-18. 